\title{
Dipicolinic acid as a tracer for thermophilic endospores and hydrocarbon seeps in deep water marine sediments
}

\author{
JAYNE. E. RATTRAY ${ }^{1 *}$, GRETTA ElIZONDO ${ }^{1}$, ANIRBAN \\ CHAKRABORTY $^{1}$, BERNIE BERNARD ${ }^{2}$, JAMES BROOKS ${ }^{2}$, \\ ADAM MACDONALD ${ }^{3}$, CALVIN CAMPBELL $^{3}$, ALEXANDRE \\ NORMANDEAU ${ }^{4}$, MARTIN FOWLER ${ }^{5}$, JAMIE WEBB $^{5}$ AND \\ CASEY R.J. HUBERT ${ }^{1 *}$. \\ ${ }^{1}$ UNIVERSITY OF CALGARY, CANADA, ${ }^{2}$ TDI BROOKS \\ INTERNATIONAL, USA, ${ }^{3}$ NOVA SCOTIA DEPARTMENT OF \\ ENERGY AND MINES, CANADA, ${ }^{4}$ BEDFORD INSTITUTE OF \\ OCEANOGRAPHY, CANAdA, ${ }^{5}$ APPLIED PETROLEUM \\ TECHNOLOGY LTD., CANADA.
}

(*jayne.rattray@ucalgary.ca, c.hubert@ucalgary.ca)

Understanding the sediment biogeography of dormant marine thermophilic bacterial endospores (thermospores) has the potential to assist locating and characterising working petroleum systems. The presence of thermospores in cold ocean environments suggests that distribution is governed by spore dispersal via advective hydrocarbon seepage sourced from deep hot oil reservoirs. The biomarker 2,6-pyridine dicarboxylic acid (dipicolinic acid or DPA) is specific to endospore-forming bacteria from the phylum Firmicutes, and constitutes a significant percentage of endospore dry weight. As a biomarker for sediment-dwelling endospores, DPA is a potential biomarker for detecting anomalies indicative of seabed hydrocarbon seeps, however this utility for seabed screening has so far not been tested.

To address this we established a modified $\mathrm{Tb}^{3+}$ chelation method for the analysis of DPA using HPLC coupled to fluorescence detection ${ }^{[1]}$. DPA concentrations were compared with hydrocarbon geochemistry and available seep data from deep seabed sediment samples from the Eastern Gulf of Mexico ${ }^{[2]}$ as well as from along the Scotian shelf and Laurentian channel in Atlantic Canada. Higher and more variable concentrations of DPA were observed in deeper sediment layers in hydrocarbon-positive stations compared to hydrocarbon-negative stations. We propose that DPA has potential as a biomarker for assisting in locating working petroleum systems in deep water marine environments.

[1] Lomstein \& Jørgensen (2012) L\&O Methods 10, 227-233. [2]. Chakraborty et al. (2018) ISME journal 12, 1895-1906. 